Фармацевтична технологія, біофармація, гомеопатія

Pharmaceutical technology, biopharmacy, homeopathy

Рекомендована д. фрармац. наук, проф. Т. А. Грошовим

УДК 615.454.1:615.014.4:616.147.17-007.64

DOI 10.11603/2312-0967.2017.2.7908

\title{
ДОСЛІДЖЕННЯ СТАБІЛЬНОСТІ ТА ВИЗНАЧЕННЯ УМОВ ЗБЕРІГАННЯ I ТЕРМІНУ ПРИДАТНОСТІ МАЗІ «ЕСТАН»
}

\author{
(с) Н. А. Шрам, В. Ф. Мощіц, Д. І. Дмитрієвський \\ Національний фрармацевтичний університет, Харків \\ Dmitrievski71@gmail.com
}

\begin{abstract}
Мета роботи. Дослідження стабільності мазі «Естан» в процесі зберігання та визначення умов і терміну придатності. Матеріали і методи. Об'єктом досліджень була мазь «Естан» для лікування геморою, що містить у гідрофрільній поліетиленоксидній основі лідокаїну гідрохлорид та екстракти кори дуба і насіння каштану кінського. У процесі зберігання дослідних зразків мазі за допомогою фрізичних, фрізико-хімічних, фрармако-технологічних і мікробіологічних методів визначали такі показники відповідно до вимог Державної Фармакопеї України (ДФУ): зовнішній вигляд, однорідність, масу вмісту контейнера та його герметичність, pH, розмір часток, кількісний вміст таніну, есцину, лідокаїну гідрохлориду та консервантів, мікробіологічну чистоту.

Результати й обговорення. Результати проведених досліджень показали, що мазь «Естан» $є$ стабільною при зберіганні у сухому, захищеному від світла прохолодному місці протягом 2 років. Зберігання при кімнатній температурі приводило до незначного підвищення $\mathrm{pH}$.

Висновки. Проведено дослідження стабільності мазі «Естан» для лікування геморою в процесі зберігання. Експериментально доведено, що всі показники якості препарату відповідають вимогам проекту методик контролю якості. Встановлено режим зберігання мазі «Естан» - у сухому темному прохолодному місці протягом 2 років.
\end{abstract}

Ключові слова: мазь; геморой; показники якості; умови зберігання; стабільність.

Вступ. Важливою проблемою сучасної медицини та фрармації залишається фрармакотерапія деструктивно-запальних захворювань прямої кишки, найбільш розповсюдженими з яких $є$ геморой, питома вага якого, за даними ВООЗ, серед усіх проктологічних захворювань складає понад 40 \% [6, 14]. Серед мешканців великих міст у індустріально розвинених країнах розповсюдженість цього захворювання набуває характеру епідемії, вражаючи близько 60 \% людей працездатного віку [4]. Лікування геморою, як і більшості проктологічних захворювань, потребує застосування комбінації діючих речовин різних фрармакологічних груп, бажано, в одній лікарській формі 3 метою вплинути на основні симптоми захворювання: біль, кровотечу, запальний процес, пошкодження слизової оболонки прямої кишки та ін. [7, 10, 13].

У сучасній проктологічній практиці при лікуванні геморою широке застосування набули засоби для місцевої фрармакотерапії, а серед них мазі. Це пов'язано з низкою їх переваг: відносна простота застосування, можливість поєднання місцевої і резорбтивної дії, менша кількість системних побічних ефектів, забезпечення на тривалий час високої концентрації діючих речовин безпосередньо в місці нанесення препарату та можливість поєднання в одному препараті декількох АФІ різноспрямованої дії [5, 11, 15].

На даний час на українському фармацевтичному ринку для лікування геморою представлено 14 комбі- нованих мазей [3], але більшість 3 них (79 \% асортименту) закордонного виробництва. Мазі, що існують, як вітчизняного, так і закордонного виробництва не повною мірою відповідають вимогам практиків, бо в більшості випадків усувають лише окремі симптоми геморою, а не впливають одночасно на весь спектр клінічних ознак та на основні патогенетичні механізми цього захворювання. До складу більшості комбінованих мазей як протизапальні компоненти входять глюкокортикостероїди (ГКС) та нестероїдні протизапальні засоби (НПЗ3), що значно підвищує вірогідність побічних ефектів терапії, оскільки відомо, що ГКС та НПЗ3 пригнічують репаративні процеси слизової оболонки прямої кишки [11]. Крім того, більшість 3 них за ціною відносяться до високовартісних.

Враховуючи вищезазначене, в НФаУ, спільно 3 ПАТ «Хімфрармзавод «Червона Зірка», розроблено комбінований препарат для місцевого лікування геморою у формі мазі під умовною назвою «Естан» 3 протизапальною, венотропною, знеболювальною, антимікробною та репаративною активністю, до складу якої включено екстракти з кори дуба і насіння каштану кінського в комбінації з місцевим анестетиком - лідокаїну гідрохлоридом. Як основу у складі даної мазі використано сплав поліетиленоксидів 400 і 1500 у співвідношенні 6,4:3,6, осмотична активність якого скорегована присутністю олії рицинової $[2,9,12]$.

ISSN 2312-0967. Pharmaceutical review. 2017. № 2 
Фармацевтична технологія, біофармація, гомеопатія Pharmaceutical technology, biopharmacy, homeopathy

Одним із важливих етапів фрармацевтичної розробки нового лікарського засобу $є$ дослідження стабільності його промислових зразків у процесі тривалого зберігання. При цьому уточнюються умови зберігання і терміни придатності. Набір показників якості для контролю досліджуваного препарату в процесі зберігання і показники якості, закладені в специфрікації, як правило, не збігаються. Тому при дослідженні стабільності рекомендовано застосовувати додаткові показники, більш чутливі і селективні методи аналізу, які дають змогу виявити навіть незначні зміни якості. Невідповідність одного із використаних критеріїв свідчить про нестабільність розробленого препарату, оскільки може призвести до погіршення споживчих властивостей та зниження його терапевтичної есрективності [1]

Враховуючи вищезазначене, метою даної роботи $€$ дослідження стабільності та визначення умов і терміну придатності мазі «Естан».

Методи дослідження. Дослідження стабільності запропонованої мазі здійснювали за такими показниками: опис, ідентисрікація та кількісний вміст діючих речовин та консервантів, однорідність, маса вмісту контейнера та його герметичність, розмір часток, мікробіологічна чистота.

Ідентифрікацію та кількісне визначення рослинних екстрактів здійснювали за їх активними складовими: есцином (для екстракту каштану кінського) та таніном (для екстракту кори дуба). Для ідентисрікації есцину використано метод тонкошарової хроматограopiï за ДФУ, а для кількісного визначення - спектрофотометричний метод при $\lambda=540$ нм 3 використанням стандартного зразка есцину. Ідентифрікацію поліфенольних сполук екстракту кори дуба здійснювали за допомогою кольорової реакції з розчином заліза (III) хлориду, а кількісне визначення методом адсорбційної спектрофротометрії у видимій області спектра шляхом визначення вмісту танінів у перерахунку на пірогалол при $\lambda=760$ нм [8].

Для ідентифрікації та кількісного визначення лідокаїну гідрохлориду та консервантів (метилпарагідроксибензоату (ніпагіну) та пропілпарагідроксибензоату (ніпазолу)) було застосовано метод високоефективної рідинної хроматографії (ВЕРХ) (ДФУ, п. 2.2.29). На хроматограмі випробуваного розчину, одержаного при кількісному визначенні, час утримування лідокаїну, ніпагіну та ніпазолу збігався з часом утримування піків лідокаїну, ніпагіну та ніпазолу на хроматограмі розчинів порівняння.

Фармако-технологічні показники (однорідність, розмір часток, маса вмісту контейнера та його герметичність) визначали за методиками ДФУ 1.0.

Дослідження мікробіологічної чистоти мазі проводили в лабораторії ПАТ «Хімфрармзавод «Червона Зірка» за методикою ДФУ 1,0 п.2.6.12, 2.6.13.
Статистичну обробку отриманих результатів фрармако-технологічних, фрізико-хімічних та мікробіологічних досліджень проводили згідно з вимогами ДФУ, Доповнення 1, п.5.3.

Результати й обговорення. Дослідження стабільності мазі «Естан» у процесі зберігання проводили на 5 серіях дослідних зразків, які зберігались у тубах алюмінієвих по 30 г. Аналіз проводили відразу після приготування і через кожні 6 місяців протягом 27 місяців зберігання.

Дослідні зразки мазі витримували при двох температурних режимах: $15,0-25,0^{\circ} \mathrm{C}$ (кімнатна температура) та 8,0-15,0 ㅇ (прохолодне місце) впродовж 27 місяців.

Результати вивчення стабільності дослідних зразків мазі «Естан» наведено у таблиці 1.

Згідно з отриманими результатами, дослідні зразки мазі «Естан» відповідають вимогам показників якості, закладених у проекті методів контролю якості (МКЯ) впродовж усього терміну зберігання. Різний температурний режим зберігання суттєво не впливає на основні показники якості мазі. За показниками «Опис» мазь протягом усього часу стеження залишалась світло-коричневого кольору, однорідної консистенції зі специфічним запахом рослинних екстрактів.

Розмір часток рослинних екстрактів, що знаходились у диспергованому стані, не перевищував 10 мкм, середня маса вмісту упаковки (туби) та її герметичність залишались у межах, передбачених в МКЯ. Кількісний вміст БАР рослинних екстрактів (есцину та таніну), лідокаїну гідрохлориду та консервантів (ніпагіну та ніпазолу) протягом терміну спостереження практично не змінювався порівняно з початковими показниками, як на момент виготовлення, що свідчить про оптимальне обгрунтування складу і технології. Однак необхідно зазначити, що показник $\mathrm{pH}$ зразків мазі, що зберігались в інтервалі температур 15,0-25,0 으 дещо вищий, порівняно 3 рН зразків, які зберігались при температурі 8,0-15,0 ${ }^{\circ} \mathrm{C}$ впродовж 2 років.

Враховуючи даний фракт та аналізуючи усі обставини, що пов'язані зі зберіганням мазі у різні пори року (при яких кімнатна температура інколи може бути вищою ніж $15,0-25,0^{\circ} \mathrm{C}$ ), рекомендовано зберігати мазь «Естан» у алюмінієвих тубах при температурі 8,0-15,0 ${ }^{\circ} \mathrm{C}$ протягом 2 років.

Висновки. Досліджено показники якості (опис; ідентисрікація та кількісний вміст АФІ і консервантів; pH; однорідність; маса вмісту та герметичність контейнера; розмір часток; мікробіологічна чистота) мазі «Естан» в процесі зберігання при двох температурних режимах: $15-25^{\circ} \mathrm{C}$ (кімнатна температура) та 8-15 ${ }^{\circ} \mathrm{C}$ (прохолодне місце) протягом 27 місяців. Визначено рекомендований термін придатності - 2 роки при температурі 8-15 ${ }^{\circ} \mathrm{C}$.

ISSN 2312-0967. Фармацевтичний часопис. 2017. № 2 
Фармацевтична технологія, біофармація, гомеопатія

Pharmaceutical technology, biopharmacy, homeopathy

\begin{tabular}{|c|c|c|c|c|c|c|c|c|c|c|c|c|c|c|c|c|c|c|c|}
\hline & $\widehat{N} \mid$ & & 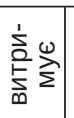 & 言产 & 言点岕 & 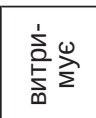 & 产宓 & 产竞 & 产音 & 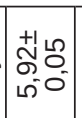 & $\mid \begin{array}{lll}+1 & 1 \\
0 & 0 \\
0 & -0 \\
m^{2} & 0\end{array}$ & 言产 & & 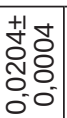 & 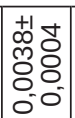 & 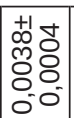 & 草志 & 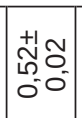 & 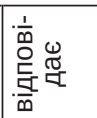 \\
\hline $\left.\begin{array}{r}0 \\
0 \\
0 \\
1 \\
0\end{array}\right]$ & 衣 & & 言意 & 言产 & 㐔竞 & 言岕 & 言产 & 言宓 & 言竞 & $\mid \begin{array}{lll}+1 & 0 \\
& 0 \\
0 & 0 \\
0 & 0\end{array}$ & 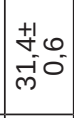 & 言产 & & 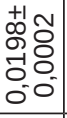 & 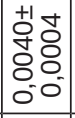 & 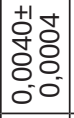 & $\mid \begin{array}{l}+1 \\
0 \\
0 \\
-i\end{array}$ & $\begin{array}{l}+10 \\
0 \\
0 \\
0 \\
0 \\
0\end{array}$ & 요료 \\
\hline 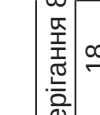 & 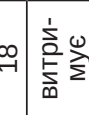 & & 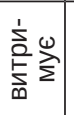 & 言就 & 产䇏 & 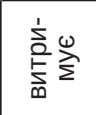 & 言产 & 产竞 & 产蒿 & 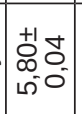 & 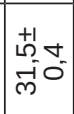 & 产竞岕 & & 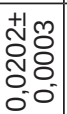 & 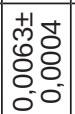 & 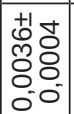 & 音告 & 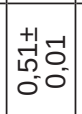 & 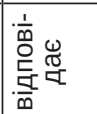 \\
\hline خ & $\underset{\sim}{*}$ & & 言䇏 & 言䇏 & 产 & 言岕 & 言意 & 产岕 & 言音 & $\mid \begin{array}{l}\text { t1 } \\
0 \\
0.0 \\
0^{-0} 0^{\circ}\end{array}$ & $\mid \begin{array}{lll}+1 & 1 \\
0 & 0 \\
0 & 0 \\
m^{2} & 0\end{array}$ & 产訔岕 & & $\begin{array}{l}0 \\
0 \\
0 \\
0 \\
0 \\
0 \\
0 \\
0 \\
-0 \\
0\end{array}$ & 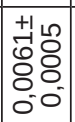 & 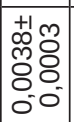 & 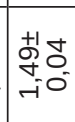 & 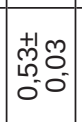 & 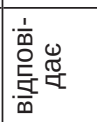 \\
\hline 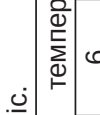 & 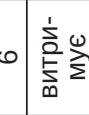 & & 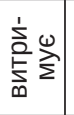 & 言 & 产岂 & 言岕 & 言䇏 & 产岕 & 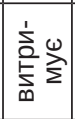 & 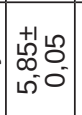 & \begin{tabular}{l}
+1 \\
\multirow{N}{*}{$=0$} \\
$\vec{m}$
\end{tabular} & 产产 & & 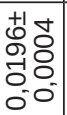 & 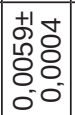 & 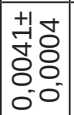 & 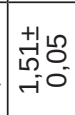 & $\begin{array}{l}+1 \\
\text { âd } \\
\text { o. } \\
0-0 \\
0\end{array}$ & 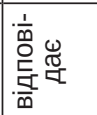 \\
\hline 立 & ذ: & & 言 & 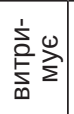 & 言岂 & 产岕 & 产站 & 产竞岕 & 言岂 & 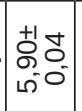 & $\mid \begin{array}{l}1+1 \\
0 \\
0 \\
0 \\
0\end{array}$ & 产䇏岕 & & 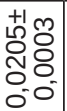 & 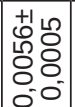 & 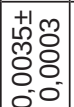 & 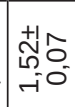 & 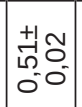 & 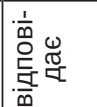 \\
\hline & 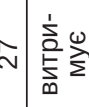 & & 言点 & 言竞 & 产产 & 言岕 & 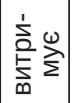 & 㐔产 & 产妾 & 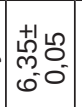 & 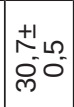 & 产产岕 & & 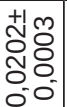 & 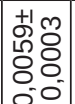 & 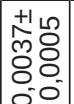 & 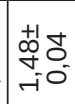 & $\begin{array}{l}+1 \\
01 \\
0 \\
0.0 \\
0.0 \\
0\end{array}$ & 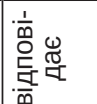 \\
\hline in & 出 & & 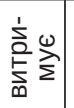 & 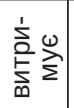 & $\mid$ & 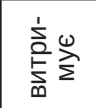 & 言咅 & 产竞岕 & 产竞步 & 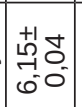 & 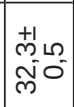 & 言竞离 & & 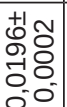 & 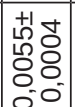 & 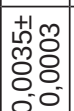 & $\begin{array}{l}+18 \\
\text { No } \\
-10\end{array}$ & 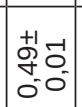 & 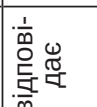 \\
\hline 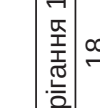 & 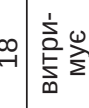 & & 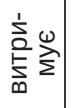 & 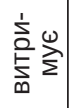 & 㐔 & 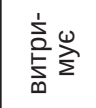 & 言䇏岕 & 产竞 & 言老 & 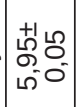 & 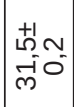 & 产产 & & $\begin{array}{l}+1 \\
0 \\
0 \\
0 \\
0 \\
0 \\
0 \\
0 \\
0 \\
0\end{array}$ & 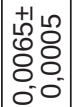 & 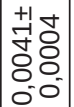 & $\begin{array}{l}+1 \\
0 \\
0\end{array}$ & 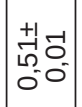 & 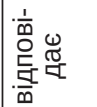 \\
\hline 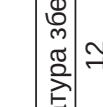 & 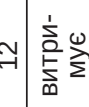 & & 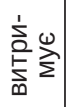 & $\mid$ & 言产 & 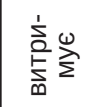 & 言䇏岕 & 产竞䁅 & 产䇏岕 & $\left|\begin{array}{lll}1 & 1 & 0 \\
0 & 0 \\
0 & 0 & 0 \\
10 & 0\end{array}\right|$ & $\begin{array}{l}\stackrel{+}{1} \\
\text { J } \\
\text { jo }\end{array}$ & 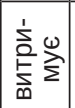 & & 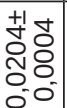 & 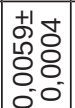 & 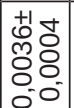 & 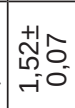 & 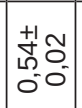 & 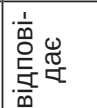 \\
\hline $\mid$ & $0 \mid \frac{1}{\vdots}$ & & 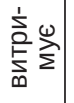 & 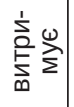 & 产育 & 言 & 言站 & 言产 & 言产 & 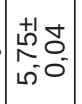 & $\begin{array}{l}+1 \\
0 \\
0 \\
0 \\
0\end{array}$ & 言育 & & 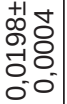 & 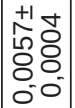 & 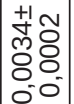 & 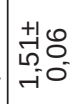 & 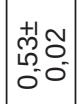 & 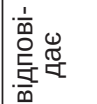 \\
\hline & 广் & & 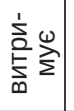 & 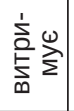 & 言妾 & 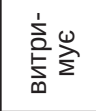 & 言产 & 言 & 言竞䍗 & 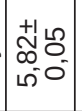 & $\begin{array}{l}+1 \\
m \\
m \\
m\end{array}$ & 言䇏 & & $\begin{array}{l}+10 \\
0 \\
0 \\
0 \\
0 \\
0 \\
0 \\
0 \\
0\end{array}$ & 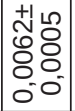 & 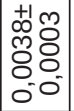 & $\begin{array}{l}\stackrel{+}{1} \hat{N}^{\circ} \\
\text { ño } \\
\text { - }\end{array}$ & 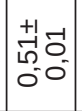 & 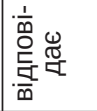 \\
\hline 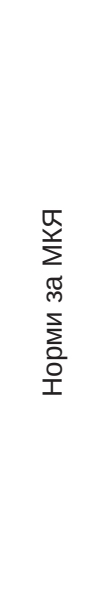 & 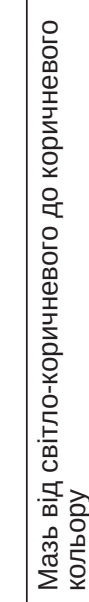 & & 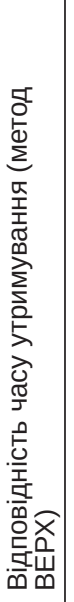 & 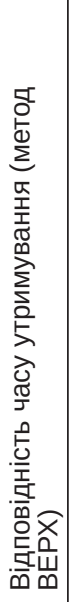 & 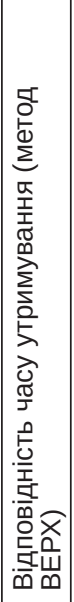 & 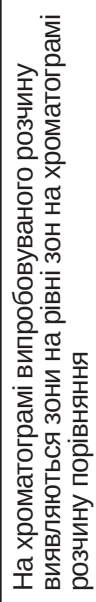 & 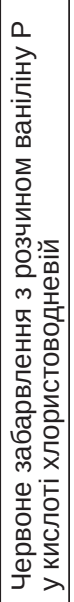 & 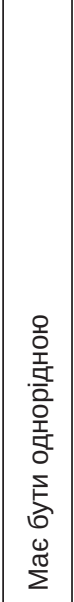 & 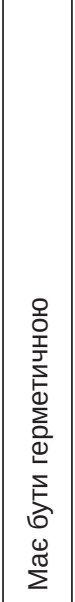 & $\begin{array}{l}0 \\
\text { î } \\
\text { in } \\
\text { in }\end{array}$ & $\begin{array}{l}0 \\
0 \\
m \\
. \overline{0} \\
.0\end{array}$ & $\begin{array}{l}\text { 엄 } \\
\text { o } \\
\text { 이 }\end{array}$ & 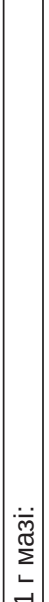 & 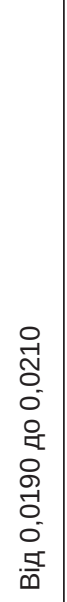 & 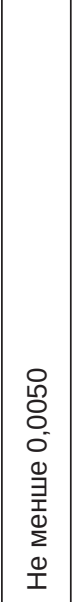 & 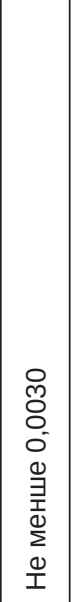 & 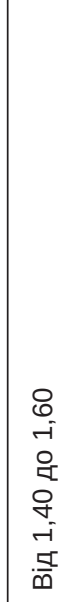 & $\begin{array}{l}8 \\
0 \\
0 \\
0 \\
0 \\
0 \\
0 \\
0 \\
. \frac{1}{0} \\
\text { - }\end{array}$ & 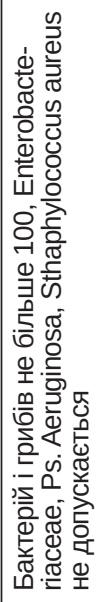 \\
\hline 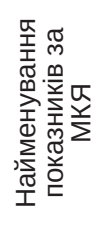 & 岂 & 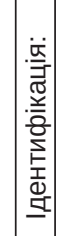 & 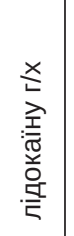 & 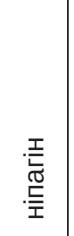 & 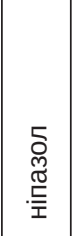 & 经 & 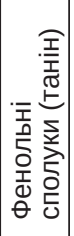 & 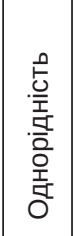 & 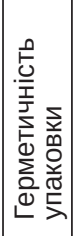 & I & 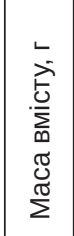 & 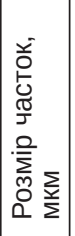 & & 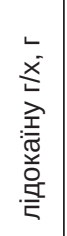 & $\overline{0}$ & 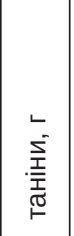 & 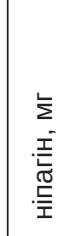 & 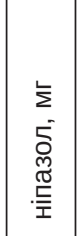 & 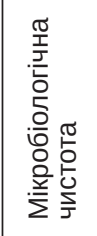 \\
\hline
\end{tabular}

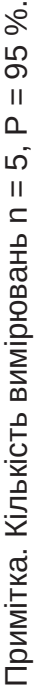


Фармацевтична технологія, біофармація, гомеопатія Pharmaceutical technology, biopharmacy, homeopathy

\title{
ИССЛЕДОВАНИЕ СТАБИЛЬНОСТИ И ОПРЕДЕЛЕНИЕ УСЛОВИЙ ХРАНЕНИЯ И СРОКОВ ГОДНОСТИ МАЗИ «ЭСТАН»
}

\author{
Н. А. Шрам, В. Ф. Мощиц, Д. И. Дмитриевский \\ Национальный фрармацевтический университет, Харьков \\ Dmitrievski71@gmail.com
}

Цель работы. Исследование стабильности мази «Эстан» в процессе хранения и определения условий и сроков годности.

Материалы и методы. Объектом исследований была мазь «Эстан» для лечения геморроя, содержащая в гидрофильной полиэтиленоксидной основе лидокаина гидрохлорид и экстракты коры дуба и семян каштана конского. В процессе хранения исследуемых образцов мази с помощью фризических, фризико-химических, фармакотехнологических и микробиологических методов определяли следующие показатели в соответствии с требованиями Государственной Фармакопеи Украины: внешний вид, однородность, массу содержимого контейнера и его герметичность, $\mathrm{pH}$, размер частиц, количественное содержание таннина, эсцина, лидокаина гидрохлорида и консервантов, микробиологическую чистоту.

Результаты и обсуждение. Результаты проведенных исследований показали, что мазь «Эстан» является стабильной при хранении в сухом защищенном от света прохладном месте в течение 2 лет. Хранение при комнатной температуре приводило к незначительному повышению $\mathrm{pH}$.

Выводы. Проведено исследование стабильности мази «Эстан» для лечения геморроя в процессе хранения. Экспериментально доказано, что все показатели качества препарата отвечают требованиям проекта методик контроля качества. Определен режим хранения мази «Эстан»- в сухом темном прохладном месте в течение 2 лет.

Ключевые слова: мазь; геморрой; показатели качества; условия хранения; стабильность.

\section{THE STUDY OF STABILITY AND DETERMINATION OF THE STORAGE CONDITIONS AND THE SHELF LIFE OF THE OINTMENT "ESTAN"}

\section{N. A. Shram, V. F. Moshchits, D. I. Dmytriievskyi}

National University of Pharmacy, Kharkiv

Dmitrievski71@gmail.com

The aim of the work. To study stability of the ointment "Estan" in the process of storage and determine the storage conditions and its shelf life.

Materials and Methods. The study object was the ointment "Estan" containing lidocaine hydrochloride and the extract of oak bark and horse chestnut seed in the hydrophilic polyethylene oxide base for treating hemorrhoid. During storage of the samples of the ointment we studied such indicators as appearance, uniformity, the weight of the container content and its integrity, $\mathrm{pH}$, particle size, the quantitative content of tannin, escin, lidocaine hydrochloride, and preservatives, microbiological purity were determined by physical, physicochemical, microbiological and pharmacotechnological methods according to the requirements of the State Pharmacopoeia of Ukraine (SPhU).

Results and Discussion. The results of the conducted studies showed that the ointment "Estan" is stable when stored in a dry cool place protected from light for 2 years. The storage at room temperature resulted in an insignificant $\mathrm{pH}$ increase. Conclusions. The study of stability of the ointment "Estan" for treating hemorrhoid in the process of storage was conducted. It was experimentally proven that all indicators of the product quality meet the requirements of the draft for quality control methods. The storage conditions for the ointment "Estan", namely in a dry dark cool place for 2 years, were determined.

Key words: ointment; hemorrhoid; quality figures; storage requirements; stability.

\section{Список літератури}

1. Аналитическая химия в создании, стандартизации и контроле качества лекарственных средств: в 3-х т. / под ред. В. П. Георгиевского. - Х. : НТМТ, 2011. - 1449 с. 2. Бездітко К. П. Експериментальне обгрунтування можливості використання нової комбінованої мазі на основі рослинних компонентів для лікування геморрою : дис. ... канд. фрармац. наук : 14.03.05 / Бездітко Катерина Павлівна. - Харків, 2009. - 179 с.

3. Бездітко К. П. Фармакоекономічний аналіз українського ринку мазей для лікування геморою / К. П. Бездітко, І. П Чикильдик // Фармакоэкономика в Украине: состояние и перспективы развития : матер.

ISSN 2312-0967. Фармацевтичний часопис. 2017. № 2 
науч.-практ. конор. - Х. : НФаУ, 2008. - С. 47-52.

4. Благодарный Л. А. Роль консервативной терапии в лечении геморроя / Л. А. Благодарный // Consilium Medicum. - 2006. - T. 8, № 7. - С. 93-96.

5. Даценко Б. М. Геморрой : монография / Б. М. Даценко, А. Б. Даценко. - Х. : Новое слово, 2011. - 144с.

6. Загрядский Е. А. Современная техника лечения острого геморроя / Е. А. Загрядный // Consilium provisorum. -2005 . - T. 3, № 2. - C. 25-29.

7. Клиническая колопроктология: рук-во для врачей / П. Г. Кондратенко, Н. Б. Губергриц, Ф. Э. Элин, Л. В. Смирнов. - М. : Медпрактика, 2006. - 385с.

8. Мощіц В. Ф. Розробка складу та технології комбінованої мазі з екстрактом кори дуба та насіння каштану кінського для лікування проктологічних захворювань : дис. ... канд. фрармац. наук : 15.00.01 / Мощіц Віктор Федорович. - Харків, 2012. - 178 с.

9. Пат. 52642 Україна. АНК 36/49, АНК 31/167, АНК 9/06, АНК 1/04. Комбінований проктологічний засіб у формі мазі / Трутаєв І. В., Мощіц В. Ф. - заявл. 28.09.2009;
Фармацевтична технологія, біофармація, гомеопатія Pharmaceutical technology, biopharmacy, homeopathy опубл. 10.09.2010, Бюл. № 17.

10. Руководство по колопроктологии / [Ривкин В. Л., Файн С. Н., Бронштейн А. С., Ан. В. К.]. - М. : Медпрактика, 2004. - 488 с.

11. Фармацевтические и биологические аспекты мазей / И. М. Перцев, А. М. Котенко, О. В. Чуешов, Е. Л. Халеева; под. ред. И. М. Перцева. - Х. : НФаУ, 2003. - 288 с.

12. Яковлева Л. В. Дослідження механізму протизапальної дії нової вітчизняної мазі «Естан» на різних меделях гострого запалення / Л. В. Яковлева, К. П. Бездітко // Клінічна фрармація. - 2008. - Т. 12, № 3. - С. 30-34.

13. Kaidar-Person O. Hemorrhoidal disease: a comprenensive review / O. Kaidar-Person, B. Person, S. D. Wexner // I. Am. Coll. Surg. - 2007. - Vol. 204, № 1. - P. 102-117.

14. Salvati E. P. Non-operative management of hemorrhoids / E. P. Salvati // Dis. Colon Rectum. 1999. - Vol. 42, № 8. - P. 989-993.

15. The vascular nature of hemorrhoids / F. Aigner, G. Bodner, H. Gruber [et al.] // Gastrointest. Surg. - 2006. - №10 (7). - P. 1044-1150.

\section{References}

1. Georgievskiy VP, editor. Analytical chemistry in the creation, standardization and quality control of medicines. [Аналитическая химия в создании, стандартизации и контроле качества лекарственных средств] Kharkov: NTMT; 2011. Russian.

2. Bezditko KP. Experimental study the possibility of using new combined ointment based on herbal ingredients for the treatment of hemorrhoids [dissertation]. Kharkiv; 2009. $179 \mathrm{p}$.

3. Bezditko KP, Chykyldyk IP. [Pharmacoeconomic analysis of Ukrainian market of ointments for the treatment of hemorrhoids]. In: Farmakoekonomika v Ukraine: sostoyanie i perspektivy razvitiya: Proceedings of the scientific conference. Kharkov: NUPh; 2008. p. 47-52. Russian.

4. Blagodarnyi LA. [The role of conservative therapy in the treatment of hemorrhoids]. Consilium Medicum. 2006; 8 (7): 93-6. Russian.

5. Datsenko BM, Datsenko AB. Hemorrhoids. [Геморрой] Kharkov: Novoe slovo; 2011. Russian.

6. Zahriadskii EA. [Modern techniques for treating acute hemorrhoids]. Consilium provisorum. 2005; 3 (2): 25-9. Russian.

7. Kondratenko PH, Huberhrits NB, Elin FE, Smirnov LV. Clinical Coloproctology. [Клиническая колопроктология]. Moscow: Medpraktika; 2006. Russian.

8. Moshchits VF. Development of technology combined ointment with extract of oak bark and seeds of horse

chestnut for treating diseases proctological [dissertation]. Kharkiv; 2012. 178 p. Ukrainian.

9. Trutaev IV, Moshchits VF. Combined Proctologic means in the form of ointments. UA 52642 (Patent) 2010 September 10. Ukrainian.

10. Rivkin VL, Fain SN, Bronshtein AS, An VK. Guide coloproctology. [Руководство по колопроктологии] Moscow: Medpraktika; 2004. Russian.

11. Pertcev IM, Kotenko AM, Chueshov OV, Khaleeva EL. Pharmaceutical and biological aspects of ointments. [Фармацевтические и биологические аспекты мазей] Kharkov: NUPh; 2003. Russian.

12. Iakovlieva LV, Bezditko KP. [Investigation of the mechanism of the new national anti-inflammatory ointment "Estan" on various Medel acute inflammation]. Klinichna farmatsiia. 2008; 12 (3): 30-4. Ukrainian.

13. Kaidar-Person O, Person B, Wexner SD. Hemorrhoidal disease: a comprenensive review. I. Am. Coll. Surg. 2007; 204 (1): 102-17. Available from: http://dx.doi.org/10.1016/j. jamcollsurg.2006.08.022.

14. Salvati EP. Non-operative management of hemorrhoids. Dis. Colon Rectum. 1999; 42 (8): 989-93. Available from: http://dx.doi.org/10.1007/bf02236687.

15. Aigner F, Bodner G, Gruber H, Conrad F, Fritsch $H$, Margreiter R, et al. The vascular nature of hemorrhoids. Gastrointest. Surg. 2006; 10 (7): 1044-150. Available from: http://dx.doi.org/10.1016/j.gassur.2005.12.004. 